\section{The hard and lonely road to science}

\section{Brenda Maddox}

Hypatia's Heritage: A History of Women in Science from Antiquity to the Late Nineteenth Century. By Margaret Alic. The Women's Press, 124 Shoreditch High Street, London E1 6JE, UK: 1986. Pp. 230. Pbk £4.95. To be published in the United States by Beacon Press, Boston.

THE belief that the intellectual woman's place is in the humanities dies hard. When women do enter science, they are widely expected to keep to the gentler side. As the Queen Mother once said when visiting a University of London college: "Surely only girls do botany!".

In Hypatia's Heritage, Margaret Alic musters a great deal of historical evidence to show that women have always been active in scientific thought and research. Ms Alic, a molecular biologist who has taught a course on women and science at Portland State College in Oregon, rejects entirely Freudian musings that men's scientific adventurousness may be an extension of their curiosity about their mother's body - in other words, that they are driven by a sense of mystery about the natural world which women do not have.

Her case, surprisingly, neither begins nor ends with Rosalind Franklin, who modern feminists have argued did not get fair recognition for her contribution to the discovery of the double helix. It begins instead in prehistory, when, according to Ms Alic, women as food-gatherers became versed in horticulture and agricultural science. It ends just before Marie Curie. After Madame Curie, the author believes, the structure of science changed, amateurs gave way to professionals, and qualified women could advance, although with difficulty.

Yet, in between, a great number of distinguished women scientists suffered from having others enjoy the fruits of their research. For centuries women's scientific work was published anonymously or under the name of a husband or colleague. The heroine for whom the book is entitled - Hypatia of Alexandria - was a fourthcentury astronomer and mathematician who wrote widely on the development of algebra and Ptolemian astronomy. Much of Hypatia's writing appeared under the name of Theon, who revised Euclid's Elements of Geometry. (Hypatia came to an unhappy end, drawn and quartered, not for her sex but for her refusal to convert to Christianity.)

According to Ms Alic, women scientists fared well in the Middle Ages. The cloisters and convents allowed them intellec- she would hide crookedness or lameness; the parade of it can only serve to draw on her ... envy ... and hatred".

As a feminist book, Hypatia's Heritage is happily unpolemical but a tiny bit dull. It bears the stamp of the lecture notes from which it was drawn; example is piled upon example like brick upon brick. A touch of the Germaine Greers might have helped, but then a tone of crusading passion would have been inappropriate. The author does not seem to see enormous progress but rather that, at the end of thousands of years of history, women of science still face a hard and lonely road. It is still true, she concludes, borrowing the words written by Henrietta Bolton in Popular Science Monthly in 1898, that "as a general rule the scientific woman must be strong enough to stand alone, able to bear the often unjust sarcasm and dislike of men who are jealous of seeing what they consider their own field invaded".

Brenda Maddox, 9 Pitt Street, London W8 $4 N X, U K$, is a journalist and author.

\section{Myth in the making}

\section{Derek Paddon}

The Fifth Generation Computer: The Japanese Challenge. By Tohru Moto-oka and Masaru Kitsuregawa. Translated by F.D.R. Apps. Wiley:1985. Pp.122. Pbk $£ 8.95, \$ 17.95$.

IN under 30 years computer technology has spanned four generations: the electronic valve, transistors, large scale integrated circuits on silicon and very large scale integrated circuits (VLSI). The fifth will combine VLSI technology and artificial intelligence to give the most advanced and influential machine in the history of mankind. A project to build such a machine was announced by the Japanese in 1981; international response was swift and other national projects were quickly set up.

According to Professors Moto-oka and Kitsuregawa, the fifth-generation computer will be the leading computer in the 1990s. The areas of application of these machines will be vast - in offices, classrooms, factories and laboratories, for language understanding and translation, picture processing, making business decisions, government policy-making, and improving productivity in manufacturing and public services; in other words, they will aid us in all activities that require mental ability.

Moto-oka and Kitsuregawa have produced a very readable account of the aims and background of the fifth-generation project. The technical demands on the reader are low; certainly, non-specialists will find it readily comprehensible. Unfor- tunately, however, the research aspects of the book are very misleading. If the fifthgeneration computer is to become a reality, many fundamental research problems must be solved, ranging from its basis of "strong" artificial intelligence to the novel computer architecture it will require. The authors imply that incremental development will resolve these difficulties; that, quite simply, seems unlikely.

During the early stages, the view emanating from Japan was that the Institute for New Generation Computing (ICOT), located in Tokyo, was solely responsible for research, with hardware support coming from the Japanese electronics companies. The authors continue to convey this image. Those familiar with Japanese industry, however, regard ICOT as but the focal point of the research and not the mainstay of the national effort. If this is not so, we are supposed to believe that some 70 personnel will succeed where thousands of IBM engineers and scientists have not.

I regret, then, that the authors did not give an analysis of the fifth-generation project as seen three years on. Instead we again have to be satisfied with a contradictory account which leaves us asking the same questions that have remained unanswered since 1981.

Derek Paddon is in the Department of Computer Science, University of Bristol, Bristol BS 8 $1 T W, U K$

\section{Spring books}

Next week's issue of Nature includes the Spring books supplement. Reviewed are the autobiographies of P.B. Medawar and Rudolf Peierls, a biography of Max Delbrück, and books by Julian Schwinger, Bernard d'Espagnat, Elliot Valenstein, Niles Eldredge, Linus Pauling, Harry W. Paul and John Maynard Smith. 